\title{
ROUTLEDGE HANDBOOK OF GENDER AND AGRICULTURE
}

Edited by Carolyn E. Sachs, Leif Jensen, Paige Castellanos, and Kathleen Sexsmith

First published in 2021

ISBN: 978-0-367-19001-9 (hbk)

ISBN: 978-0-429-19975-2 (ebk)

Chapter 13

GENDER AND THE POLITICAL ECONOMY OF FISH AGRI-FOOD SYSTEMS IN THE GLOBAL SOUTH

Surendran Rajaratnam, Molly Ahern, and Cynthia McDougall

(CC BY-NC-ND 4.0)

This OA chapter is funded by WorldFish. 


\title{
13 \\ GENDER AND THE POLITICAL ECONOMY OF FISH AGRI-FOOD SYSTEMS IN THE GLOBAL SOUTH
}

\author{
Surendran Rajaratnam, Molly Ahern, and Cynthia McDougall
}

\section{Introduction}

Fish are a well-recognized and often irreplaceable source of bioavailable micronutrients and animal protein in many developing countries, with some countries relying on fish for around half of the animal protein supply (Ababouch and Carolu, 2015). The demand for fish continues to rise due to global recognition of its nutrition and health benefits (Ababouch and Carolu, 2015; Ayoola, 2010). Fishing and aquaculture activities support the livelihoods of 660-820 million people, with over $90 \%$ of those living in developing countries and working in small-scale operations (Ababouch and Carolu, 2015). Given their critical role in livelihoods, food, and nutrition security, and the wellbeing of the people of the Global South, fish, fisheries, and aquaculture are key entry points to improve development outcomes through food systems (Box 13.1).

\section{Box 13.1}

Capture fisheries and aquaculture production have increased in the last three decades (Msangi et al., 2013). However, the relationship between the two production systems and food outcomes is complex and needs further investigation. The development of aquaculture has been considerable and high profile, yet uneven; $90 \%$ of total aquaculture production globally takes place in Asia, whereas Africa produces less than 2\%, half of which is produced in Egypt (Ababouch and Carolu, 2015). In addition, there are concerns that fish from aquaculture may not reach the poor (Golden et al., 2017), as it may serve the market demand of those most able to pay (Cohen et al., 2019). At the same time, there is growing evidence that the role of capture fisheries in food and nutrition security - providing essential nutrients and protein to tens of millions of people in the Global South, in particular, Africa - may be underestimated and undervalued to date (Campling et al., 2012; Belton and Thilsted, 2014; Funge-Smith and Bennett, 2019). 
Fish is produced both through small-scale (traditional and artisanal) and large-scale (commercial and industrial) capture fisheries and aquaculture. Traditionally a food and livelihood activity for fishing communities, political strengthening of the environment for private investment, exports, and cross-border trade has transitioned fish to a global commodity (Campling et al., 2012). Fish represents USD 164 billion in exports as of 2020 (FAO, 2020), of which 54\% originates in developing countries (World Bank, 2019; FAO, 2020). While emerging blue economy or blue growth investments and discourse frame the oceans as the "next economic frontier," there is mounting concern that small-scale fisherfolk may be crowded out by more powerful economic or environmental conservation interests that are focused on maximizing monetary or environmental values while dismissing the livelihoods and ability of small-scale fishers to produce affordable, nutrient-dense food for themselves and other consumers (Cohen et al., 2019; Béné et al., 2016; Tlusty et al., 2019).

As fish has transformed into a global commodity, complexities and unknowns have arisen in the dynamics between fisheries, aquaculture, markets, and development outcomes. A recent study indicates that some developing countries' wild catch would be enough to ameliorate micronutrient deficiencies if kept for domestic consumption (Hicks et al., 2019). The first Illuminating Hidden Harvest study highlighted underreported catch from global inland capture fisheries, primarily due to undercounting the importance of small-scale sectors, which produces as much fish as large-scale sectors for direct human consumption in areas with high rates of poverty and malnutrition (World Bank et al., 2012). While the growth of fish exports from the Global South contributes to the gross domestic product (GDP) of Southern countries, it is simultaneously critiqued as undermining food security in developing countries (Biswas, 2011; Alder and Sumaila, 2004). As a part of this, even though nutritious wild fish is produced and traded more often in low-income countries (Thilsted et al., 2016), in some systems, they are prioritized for aquaculture feed rather than direct human consumption, which is especially problematic for nutritionally vulnerable populations (Greenpeace, 2019). That being said, there is also evidence of the significance of small-scale aquaculture for food and nutrition security, especially in Asia. For example, in India, Kumar and Dey (2006) note that farm households that engaged in aquaculture had $10.9 \%$ greater energy intake and lower prevalence of undernourishment than wage-earners' households.

Gender dynamics represent a key element of the fishery and aquaculture systems and a determinant of their outcomes - as well as a nested set of inequalities. Women's unpaid, low paid, and reproductive labor heavily subsidizes the fishing economy (Biswas, 2011). Women's reproductive activities absorb the costs needed to be borne by the state for working poor fishing families (Biswas, 2011), and their cheap labor subsidizes capitalist fisheries by keeping wage levels in the industry low (Connelly and McDonald, 1983). Current development policy and discourse highlight the instrumental value of challenging gender inequalities, underscoring the instrumental value of women's empowerment for growth and development. For example, more broadly, studies have shown that when women are involved in livelihood activities or have access to income, they tend to spend on household requirements, such as children's education and food, thus ensuring nutrition and health security (Smith et al., 2003). In aquaculture, similar studies have surfaced on this instrumental value of empowerment. For example, women's active involvement in polyculture fish farming led to increased yields, household consumption, and improved nutritional status for the family (De et al., 2012). Conversely, aquaculture and fisheries investments that do not engage in an informed way with gender dynamics can have limited or perverse outcomes.

Despite the inequities and the imperative to address them, the sectors' engagement with gender to date has been limited. We highlight three aspects here. First, women's contributions, 
including labor, are undercounted in fisheries and aquaculture sector data (Biswas, 2018). This contributes to gender-biased or blind policies and programs in the fisheries and aquaculture sectors (Frangoudes and Gerrard, 2018; Brugere and Williams, 2017), which affects women and men differently (Kleiber et al., 2017). It results in inadequate funding and investment in economic sectors where women are concentrated, further marginalizing and undervaluing their work (Biswas, 2017; Aregu et al., 2017). Second, where the sectors do engage with gender, they tend to stop at a focus on roles ("what women do, what men do"), on women-targeting, and "women in" framings, risking "empowerment lite"1 [see Cornwall, 2018]), or limiting the scale of analysis to the micro-level, lacking the broader fishing context (Kleiber et al., 2014). Gender studies in fisheries and aquaculture tend to be local or at the household level, highlighting key issues in fisheries social sciences but lacking traction in broader economic, ecologic, and political arguments for ocean governance (Cohen et al., 2019). Critical analysis of women and men within rapidly changing sector dynamics is important to:

ensure that our sector is not weakened by dividing it, putting men on one side and women on the other, in a context where increasingly small-scale fishers from the North and South are having to abandon their way of life due to the impact of government policies which favor industrial fisheries interests. ${ }^{2}$

(Biswas, 2011, p. 58)

Third, the tendency to engage with women in the sectors (and in development more generally) as a homogenous group, undermines effective policy and programming because it overlooks the differential access to and control over resources and varying experiences that women (and men) face based on their age, class, race, marital status, or social characteristics.

These limitations underscore the need to shift focus in our understanding of fisheries and aquaculture from targeting of single issues to considering a more comprehensive set of socioeconomic, environmental, and health and wellbeing dimensions (Tlusty et al., 2019), including social justice, and applying a gender lens that looks across scales and is intersectional. In this chapter, we aim to contribute to addressing this need. We do so by diving into small-scale and commercial fisheries and aquaculture through a gender lens to look at the political (state), economic (markets), and local (household) environments, to connect the fisheries' social sciences with the blue economy in order to answer the following questions:

- How do key political economy trends of feminization, migration, and labor play out and influence the experiences, opportunities, and challenges of women and men in commercial and small-scale fisheries and aquaculture?

- What are the gender dynamics in commercial and small-scale fisheries and aquaculture, and in what ways are the experiences, opportunities, and barriers the same or different for different women and men?

- Overall, how do these commercial and small-scale sectors shape and represent opportunities for or barriers to equitable and decent livelihoods for women and men in the global South?

\section{Global trends: feminization, migration, and exploitative labor}

Here, we apply a political economy and gender lens to highlight patterns in three interacting trends that the literature identifies as pertinent in fish agri-food systems: feminization, migration, and exploitative labor. 
Women's broadened and deepened involvement in agricultural production because of their increasing responsibility for household survival and their response to economic opportunities in commercial agriculture can be referred to as the "feminization of agriculture" (LastarriaCornhiel, 2006). Similar to the agriculture sectors, the fisheries and aquaculture sectors are experiencing feminization with male outmigration (Kusakabe, 2002). This has both positive and negative implications. On the one hand, it leads to women facing increasing workloads (Ashaletha et al., 2002; De and Pandey, 2014). Male outmigration for multi-day commercial fishing or to cities for work leaves women with a greater work burden both outside of the house (in commercial and small-scale fisheries and aquaculture work) as well as domestic duties (De and Pandey, 2014; Kusakabe, 2002; Ashaletha et al., 2002). On the other hand, it is argued that it leaves space for women's involvement in fisheries and aquaculture to increase in importance (Kusakabe, 2002; Rubinoff, 1999), and gives women more space for decision-making and income-generating opportunities (Wrigley-Asante, 2011). Migration is not only a male phenomenon, however. In some Asian countries, women comprise the majority of migrants, and globally, half of all migrants are women, resulting in a "feminization of migration" (Weeratunge, 2010). In the fisheries sector, both fishermen and fisherwomen migrate across national boundaries in pursuit of better fish catches and seeking incomes. At the borders of Cambodia and Thailand, women are concentrated in small-scale trading while men are in transportation and trade on a larger scale (Kusakabe et al., 2006). Women's lack of capital and resources to store unsold fish and relatively less connection with government officers prevents them from moving beyond small-scale trading in the fish supply chain (Kusakabe et al., 2006).

In the informal sectors and fish trade, multiple studies have revealed gendered exploitative labor in the form of transactional sex for fish. This is most common in Southern Africa and is a coping strategy for women who lack capital or use sex to build business relationships with men that consequentially result in a higher prevalence of HIV/AIDS in migrant fishing communities, especially in Southern Africa (Weeratunge et al., 2010). Women who take part in transactional sex for fish are often migrant fish traders, young and single or older, widowed or divorced women, revealing that marital status is important for access to fish, while in contrast, men's marital or migration status affected the likelihood of them partaking in transactional sex (Kwena et al., 2013). Campling et al. (2012, p. 189) wrote that "women must choose between flexible but uncertain livelihoods selling reef fish, trading sex for low-quality salt fish, and the new option of highly disciplined low-waged labor in fish processing plants."

In terms of commercial labor, while commercial fishing vessels often recruit young men, as inferred above, fish processing factories often recruit women. While data is limited, as described in the following sections, seafood processing factory work has been reported as being characterized by low pay and poor conditions (Williams, 2010; Choudhury et al., 2017). It is not only women, however, who are exploited for low-cost labor in the sectors. The long-haul fishing industry has been in the spotlight for human trafficking for labor in many countries, including Thailand and Taiwan, where the presence of men in labor trafficking for multi-day fishing trips outweighs women (Yea, 2012).

Resurreccion (2006) raises the point that gendered exploitative labor may be unintentionally entrenched by the development sector. Because women's work may not be economically accounted for, development programs have been found to treat women's time as elastic. Engaging women (women-targeting) may inadvertently add to women's workloads, further subjecting them to male authority and perpetuating gender inequality (Resurreccion, 2006). In other words, programs may unintentionally add to women's workloads, as the widely held but narrow framing of women as "housewives" assumes that women are available to invest their time and labor in development and community activities (Resurreccion, 2006). As noted earlier, 
this compounds the gendered division of labor inequities, with women's unpaid labor absorbing the state's responsibility for the welfare of children and the elderly in unpaid reproductive work (Biswas, 2011).

\section{Gender in commercial and industrial aquaculture and fisheries}

\section{Gender division of labor, decision-making, and implications for men and women}

Commercial or industrial fisheries and aquaculture here refers to the part of the sectors that is market-oriented (versus subsistence) and is profit-driven, characterized by large-scale operations, often utilizing mechanization and employing labor.

Capitalist modernization and state policies regulating fisheries have shifted local fisherfolks' involvement in value chains, and in some cases, created conflict between commercial and smallscale fishing communities. The Deep-Sea Fishing Policy of 1991 in Kerala, India (Aswathy and Kalpana, 2018), for example, allowed foreign vessels access to waters within 200 miles of India's coast, leading to exacerbated overfishing and livelihood crises for small-scale fishing communities (Aswathy and Kalpana, 2018). Policy prescriptions laid out in the Washington Consensus in the 1980s led to economic restructuring in borrowing countries. This included policy changes in fisheries toward promoting export-led growth, deregulation of international trade and crossborder investment, and "labor market flexibility". The "labor market flexibility" is critiqued as a euphemism for poor wages, poor working conditions, and casual labor that exploits women disproportionately (Biswas, 2011).

Against this backdrop, the gendered division of labor in the commercial sector has been characterized by land and sea, with resource-related jobs generally dominated by men (Aswathy and Kalpana, 2019; Pini and Leach, 2011). Men are predominantly involved in fish harvesting, and while some women work on commercial fishing boats, they tend to dominate more in pre- and post-harvest activities (Lebel et al., 2011). This processing involves labor-intensive work such as washing, scaling, drying, sorting, packing, and icing fish.

This gendered division of labor reflects and shapes the different experiences of and outcomes for women and men in the commercial sector. As noted, while men may face unsafe conditions at sea, women work long hours in unhygienic or unsafe processing or factory conditions. Moreover, various studies have signaled gendered inequities playing out systematically in the commercial sector in the form of women being paid lower wages than men, experiencing abuse and harassment in the workplace, and being disproportionately exposed to health problems (Ayinla, 2003; Ashaletha et al., 2002; Choudhury et al., 2017; Jeebhay et al., 2004; Rashid et al., 2016; Williams, 2015). Women have little decision-making ability and power in industrial fishing governance (Lentisco and Lee, 2015), and are often excluded from management and higherlevel positions in commercial fisheries and aquaculture value chains (Halim, 2004).

Unpacking this further, women's (and men's) experiences are shaped by the type of work and intersectional factors. In terms of the former, although women are generally engaged in lower-paid work than men overall, income varies across female-dominated jobs with waged work, such as sorting, grading, and peeling, being lower-paid and entrepreneurial work, such as fish vending, curing, and value-added activities, being higher-paid, at least in some contexts (Rubinoff, 1999; Sari et al., 2017). Applying an intersectional lens, women's (and men's) economic opportunities are shaped by class, age, and race, and other socioeconomic characteristics (Britwum, 2006). In Ghana, for example, women's economic success can be determined by access to economic resources and the social relations that structure this access; for example, access to fish can be dependent on blood ties and marital status, social relations that affect a 
woman's ability to negotiate (Britwum, 2006). In Goa, India, female migrants from other Indian states and young, single and Hindu women have been found to be more often exploited in lower-paid work, while older, married, and Christian women were found to experience greater mobility, income control, and better outcomes (Rubinoff, 1999). Similarly, social networks, education, initial capital, or access to finance shape women's access to fish (although their success often still depends on men, when women are not allowed to go to sea) (Lentisco and Lee, 2015; Britwum, 2006). These intersectional influences interact with economic trends. A study in Kerala, India, for example, found that capitalist modernization of fisheries has placed women at different positions in the distribution network based on education and household economic status, although women remained subordinate to men as men had adopted more sophisticated technologies (Aswathy and Kalpana, 2018). Those women with direct access to fish through their own or family fishing activities are better off than secondary or tertiary users who must make business arrangements with fishermen to receive fish in exchange for a portion of the profits, or purchase fish to process and sell, often for lower profit margins than primary users (Britwum, 2006; Lentisco and Lee, 2015).

Gendered labor in commercial fisheries and aquaculture reflects not only the influence of policies that may lack gender-responsiveness but also the strong influence of social and gender norms. Norms are the "informal rules" that inform women's and men's roles and responsibilities, decision-making, and access to resources in the workplace and in the household (Ashaletha et al., 2002; Aregu et al., 2017; Aregu et al., 2018; Bennett, 2005; Locke et al., 2017). Social and gender norms in many places restrict women's mobility and the types of work that they can be involved in, confining women to fishing activities near the home, and strongly discouraging them from fishing alone or seeking work away from home (Ashaletha et al., 2002; Kusakabe, 2002). A woman's freedom to work outside of the home is often a measure of her low status or poverty (Rubinoff, 1999). For example, in India, if a woman works away from home, there may be a social perception that the husband is unable to provide for the family (Ashaletha et al., 2002). Work outside of the home, for example in fish processing plants, often puts a strain on the woman's time to complete household activities, which can cause friction and even violence in the household, resulting in women working outside of the house only out of necessity (Wahed and Bhuiya, 2007). In addition, women are constrained by lack of representation in cooperatives, less interaction with development agencies and extension officers, lack of support from husbands, and wage discrimination (Ashaletha et al., 2002).

The industrialization of fisheries and aquaculture has changed the nature and experiences of rural women's employment (Islam, 2008; Lebel et al., 2011). In some cases, there is evidence of it contributing to less constraining shifts in social norms and division of labor in some regions of the world. For example, in the Philippines, older women are becoming primary providers for the household due to their husband's roles in fishing decreasing with age, as they are unable to participate in multi-day fishing trips on commercial fishing boats (dela Pena and Marte, 2001). In India, it became more acceptable for women (especially older women) to travel far from the house to commercial fish-landing sites to purchase fish at wholesale prices for processing (Hapke and Ayyankeril, 2004).A similar shift is seen in Ghana, where women are not stigmatized (as they may be in other areas of Africa) for speaking loudly, using physical strength, or exercising power over others in the fish markets, and men have increasingly taken on traditionally female tasks associated with food provisioning (Overa, 2007).

At the same time, industrialization and commercialization have contributed to compounding gendered burdens or barriers. From a labor perspective, as noted above, men's engagement in multi-day fishing labor may increase women's workloads. Moreover, as commercial fisheries and aquaculture have created employment (albeit low paid) for women in processing and market- 


\section{Surendran Rajaratnam et al.}

ing, it has also increased women's total workload as there has not yet been a corresponding shift in the domestic gender division of labor. In other words, even as they join the paid workforce, women continue in many contexts to be expected to fulfill traditional gender roles of domestic chores and caretaking (Shah, 2010). In addition to increasing women's work burdens, this can feed back into additional challenges as it can create tensions in the household (Choudhury et al., 2017). Overall, Islam (2008, p. 211) argues that the "feminization of the workforce in aquaculture is accompanied by the marginality of females, who receive lower wages and social prestige than male counterparts."

\section{Access to and distribution of resources within commercial fishing and aquaculture}

In many countries, women experience challenges to access and use technologies that could enhance their position in the value chain and increase their benefits from fishing activities. In fish processing, for example, Davies and Davies (2009) found that men dominated in using improved technologies, while women continued to use traditional techniques and experience greater post-harvest losses and significantly lower capacity to process fish than their male counterparts using improved methods. Similarly, despite the presence of more efficient smoking kilns in Sierra Leone, Browne (2002) found that women were using more rudimentary smoking methods, possibly due to lack of training or lack of access to the kilns. Similarly, mechanization, more broadly, has had gendered outcomes favoring men. In India, the mechanization of fisheries has led to heightened efficiency in the male-dominated fish-harvesting sector, accentuating the role of women as processors and marketers, thus increasing women's work burdens, especially if they do not have access to improved technologies (Ashaletha et al., 2002). Increased competition due to cold storage and iced fish sold by men in markets in Kerala, India, led to longer workdays for women and greater distances traveled to commercial landing sites. Additionally, norms and access issues that restrict women's use of motor vehicles limits the distance they can travel to purchase fish or may limit the quantity they can carry per trip (Aswathy and Kalpana, 2018; Ashaletha et al., 2002; Fröcklin et al., 2013).

However, a few cases in the literature also demonstrate positive outcomes for women's access to technology as a result of mechanization. In the case of fishwives and fish-mammies in Ghana, the increase in production due to modernization opened new opportunities for women to access social capital and networks, enabling them to secure control over technology and resources (Lentisco and Lee, 2015). The mechanization of fishing activities broke barriers for women in the Ivory Coast, as boats with motors reduced the need to paddle and winches for drawing in the fishing net reduced physical demands that traditionally justified men's roles in fish production (Britwum, 2006).

In terms of other resources, as traditional gender roles confine women to reproductive work and household duties, women have historically lacked their own savings and assets to grow their business relative to men. Furthermore, access to assets for collateral is often a necessity when applying for a loan or microcredit to cover startup costs or to grow a business, and due to a lack of assets or savings, women may resort to borrowing money from their husbands or a male family member (Fröcklin et al., 2013). Women may also be excluded from assets, such as commonpool resources, when they become profitable. In the Mekong Delta, use of open-access lands for the collection of seaweed and aquatic resources is a critical livelihood and food security activity, especially for women and girls, however, the privatization of these lands for commercial aquaculture has stripped women of this livelihood and nutritious food source (Lebel et al., 2011). In addition to limited savings and access to land, social norms may limit women's mobility to 
go outside of the village or may prohibit young women from using motorbikes on their own to reach distant markets, although flexibility in this norm is allowed for older women to use motorbikes in some areas, such as in southern India (Aswathy and Kalpana, 2018).

\section{Gender in small-scale aquaculture and fisheries}

\section{Gender division of labor, decision-making, and implications for women and men}

Similar to the commercial sector, much of the literature signals a gender division of labor in small-scale fisheries. There is generally an emphasis on men as harvesters and women as processors and involved in food preparation, although this may be overstated in the literature. This, for example, overlooks the multitude of women who harvest fish in various ways as well as neglecting gleaning (often carried out by women) as a key form of fisheries' harvest. The key roles often associated with women in small-scale fisheries and aquaculture include repairing nets, selling products, preserving products, financing the fleet, caretaking, domestic duties, subsistence farming, and ensuring household food security (Lebel et al., 2011; Bennett, 2005; Resurreccion, 2006). Men are traditionally more associated with operating boats to go fishing, fishing for higher-value species, and harvesting fish from ponds (Aswathy and Kalpana, 2018; Fröcklin et al., 2013). Connecting these, the thread that is less recognized is that in women's unpaid domestic work, subsistence activities, such as reef gleaning, marketing, pre- or post-harvest activities like net mending, and work in other sectors, subsidize men's ability to participate in fishing (WorldFish Center, 2010; Biswas, 2011). Several authors suggest that the fishing economy would collapse without women processing and selling fish for money (Biswas, 2011; Harper et al., 2013; Brugere and Allison, 2008; Resurreccion, 2006).

This broad picture notwithstanding, gendered engagement in small-scale fisheries and aquaculture varies by context as well as in relation to socioeconomic factors, such as class or caste. In Bangladesh, for example, women mend nets, whereas, in Southeast Asia, this is typically a man's job (Kusakabe, 2002). In Laos, women operate motorized boats and gill nets while men dive (Kusakabe, 2002). In Nigeria, women formulate feed, feed fish and clean and stock ponds, while men are in charge of pond construction, medication, and spawning (Ibrahim, 2011). In India, women tend to work in fish processing, weaving gill nets, and selling fish door-to-door, although this is primarily women from lower caste groups (De and Pandey, 2014).

Across contexts, one common theme is that gendered barriers constrain women's participation in and returns from small-scale fisheries and aquaculture (Weeratunge et al., 2010). These barriers include the gendered distribution of labor (in which women need to balance productive and reproductive work), access to capital, access to raw materials (including fish), lower education levels, lack of assets and access to technology, transportation problems, poor market links and networks, including low access to extension officers, and constraining social norms around "gender-appropriate work," mobility, household chores, and dominance by spouses (Lebel et al., 2011; Lentisco and Lee, 2015; Ibrahim et al., 2011; Agbebi and Fagbote, 2012; Agbontale, 2009; Siamomua-Momoemausu, 2005; De and Pandey, 2014; Aladetohun, 2010). In Kenya, for example, in terms of normative barriers, women are prohibited from going out on boats to fish, as there are beliefs associated with womanhood and holiness, and monthly menstruation is believed to annoy the water gods (Kamau and Ngigi, 2013). Cultural boundaries in India restrict women's mobility and communication with men, making it difficult for women to access extension services (De and Pandey, 2014). When women are involved in fish harvesting in various contexts, they often fish on a smaller scale, using rudimentary technologies such as baskets, and for lower-value species (Rajaratnam et al., 2016; Lentisco and Lee, 2015). Similarly, 


\section{Surendran Rajaratnam et al.}

Cole et al. (2018) found that the inequitable distribution of unpaid care work increased women's post-harvest losses in small-scale fisheries. A value chain analysis conducted with fisherwomen along the coast of Lake Victoria, Kenya, revealed that women are located in the lower nodes of the value chain, where returns are low. The majority of the women were fish traders, with only $7 \%$ involved in fish processing and 3\% involved in fish harvesting (Kamau and Ngigi, 2013). These multi-scale and gendered patterns are also evidenced in small-scale fisheries decisionmaking (governance). In some cases, adopting or creating new governance systems can undermine or disrupt local governance structures, and some development project interventions have reduced the access to fisheries resources and decision-making power women formerly had in local regimes (Weeratunge, 2010). In other cases, such as the Barotse Floodplains of Zambia, while there is a dual system of governance for land and water rights for fishing, the traditional authority is recognized over the state as controlling access to fishing grounds (Rajaratnam et al., 2016). Yet the majority of traditional leaders are men, and men primarily inherit water rights and benefit from charging fees to outsiders to fish.

When barriers are reduced in small-scale fisheries and aquaculture, studies suggest that there are positive outcomes for women and food systems. In Cambodia, for example, household ponds where women carried out at least $50 \%$ of fish culture tasks resulted in higher yields (Nandeesha, 1994). Small-scale aquaculture projects in Vietnam recorded benefits such as better nutrition and improved income, which women used to pay for schooling for children, improved technical knowledge for women, strengthened women's unions, and improved bargaining power (Lebel et al., 2011). Given constraints due to a lack of capital, microfinance institutes have become involved with women in aquaculture value chains in Bangladesh, Sri Lanka, Thailand, and India, with results suggesting improved women's empowerment and better outcomes for food security and economic growth (Aladetohun, 2010). These are not linearly achieved, however, or readily gained through simply targeting women, as evidenced by Scarborough et al. (2017), who found the intra-household gender asset gaps increased in a small-scale aquaculture program, despite women-targeting. Choudhury et al. (2017) and Sari et al. (2017) similarly highlight that engagement of women in small-scale (and commercial) production and value chains is not sufficient for empowerment unless underlying barriers, including gender distribution of labor and constraining norms, are addressed.

\section{Access to and distribution of resources in small-scale fisheries and aquaculture}

Women's access to fish through primary, secondary, or tertiary access reveals much about gender dynamics and power dynamics and significantly influences outcomes. Primary users have access to their own catch, secondary users receive fish or make deals with their husband or family members to process fish in exchange for a portion of the profits, and tertiary users must rely on purchasing fish from the market for resale, often at lower profit margins (Lentisco and Lee, 2015). In Kerala, fish-vending women had business for about 300 days per year, whereas fishermen's incomes were more seasonal (100 days per year), suggesting that women's diversified access to fish through their own catch and purchase for sale offer a more stable income across the year (Aswathy and Kalpana, 2019). However, most fisherwomen have only secondary or tertiary access to fish, and their access to and control over resources tend to be limited (Lentisco and Lee, 2015). Power structures often marginalize women, and as tertiary users with less power and fewer assets, women may resort to harmful practices such as sex-for-fish transactions (Lentisco and Lee, 2015; Rajaratnam et al., 2016; Fiorella et al., 2015; Kwena et al. 2013).

In terms of access to assets, Resurreccion (2006) notes that women are generally absent in fisheries rights and access regimes, which tend to be dominated by fishermen, the military, fish- 
ing lot owners, sublease holders, and politicians (Resurreccion, 2006). In small-scale aquaculture, women tend to be excluded from access to or control over aquaculture resources. Choudhury and McDougall's (2018) study found that women more often experience psychological ownership of aquaculture resources while men claim legal ownership. The gendered nature of ownership was reported to have its own outcome based on decision-making and control that women and men are able to exert.

An interesting tension arises in small-scale aquaculture; on the one hand, homestead production offers a potential increase in women's access to and control over the fishpond and fish because of their proximity to the household and the ability of women to weave it (and cooking the fish) among their domestic work (and engage without challenging mobility norms). On the other hand, as an accommodative strategy, it could potentially be gender-reinforcing (as on its own, it supports the notion and boundaries of the homestead as the "woman's domain" and of women's time as infinitely elastic).

Power dynamics not only influence gendered access to fish but also to technologies and assets that can allow entry to the sectors or improve efficiency in production or the value chain. In addition to farmland, women need access to technologies that aid their engagement in aquaculture and fishing activities. However, women are often allocated to the use of smaller or less advanced technologies than men (Kusakabe, 2002; Lentisco and Lee, 2015). In Sierra Leone, men use motorized boats to go out to sea to fish, while women use scooping nets to fish inland water bodies and rivers - a dry-season technique that supplements household consumption, but requires a group effort, as one person must locate and disturb the fish, and the others scoop the fish once disturbed (Browne, 2002). Innovations and technologies for aquaculture and fisheries even at a small scale can be gender-exclusive, as they can require a large amount of capital, resulting in women becoming labor on other peoples' farms rather than operating their own (Lebel et al., 2011).

In terms of access to revenue, fish trade is also subject to government tariffs and licensing, and Kusakabe et al. (2008) highlight that in cross-border fish trade between Thailand and Cambodia, unexpected costs and arbitrary fees imposed by customs officers often affect women disproportionately. This appeared to be linked to women having weaker networks and perceiving that they had less negotiating power as they are expected to be subservient and obedient (Kusakabe et al., 2008). Additionally, when women do participate in fish harvesting and aquaculture, they are usually allocated control of lower-value species (Kusakabe, 2002; Lentisco and Lee, 2015).

\section{Conclusion}

Current market approaches to fish agri-food systems are supply-driven, with relatively little focus on developing countries' nutritional and livelihood needs or socioeconomic factors that drive the fisheries and aquaculture sectors. With the high number of people relying on fisheries and aquaculture for their livelihoods and nutrition in developing countries, this primary focus on fish supply for export markets to developed countries undervalues the role of fish for livelihoods, food security, and nutrition of those who rely on it most.

This review has highlighted that while both commercial and small-scale fisheries and aquaculture are critically important, they are both crosscut by macro- and micro-patterns of social and gender inequalities and inequities. The feminization of labor and migration in the fisheries and aquaculture sectors, while not without opportunities, have demonstrated risks and negative effects on health and wellbeing. Exploitative labor practices affect both women and men in the sectors, including further exacerbating uneven work burdens. Insufficient recognition of gender and social dynamics, including women's unpaid and paid contributions to the fisheries 
and aquaculture sectors, restrictive social norms and gender roles, and gender-blind policies contribute to the dearth of enabling environments for women to engage equitably in safe and fair work in the fisheries and aquaculture sectors. Micro-scale inequities are nested within larger dynamics - cross-cutting commercial and small-scale sectors-in which small-scale fishers and workers have relatively little say in, or returns from, the sector's opportunities or risks. These contribute to fishery- and aquaculture-dependent women - and men-taking precarious and low paid work in order to support themselves and their families. The analysis underscores the risk that —if not explicitly addressed—already economically impoverished communities and less powerful actors may be pushed into situations of greater vulnerability.

This chapter has applied a lens that makes explicit links between gender and the political economy. This type of integrated investigation can help to explore the interconnected drivers, patterns, challenges, and opportunities in fisheries and aquaculture for different groups of women and men beyond a single sector or scale. This review suggests that future research incorporates further depth in terms of contextually important intersecting identities to illuminate patterns of engagement in and benefits derived from the sectors. Furthermore, research that generates a sharper understanding of the relative and relational aspects between genders-and among various actors-within fisheries and aquaculture will help unravel barriers and leverage points to address these in order to "level the playing field" for women in the emerging blue economy and blue growth. Future research can contribute by further investigating formal and informal interactions and outcomes of public policies, civil society and private sector investments and how these can align for a more equitable, nutritious, and sustainable blue future.

\section{Acknowledgments}

This work was undertaken as part of the CGIAR Research Program on Fish Agri-Food Systems (FISH) led by WorldFish. The program is supported by contributors to the CGIAR trust fund. The publication benefited from reviews by Philippa Cohen (WorldFish) and Carolyn Sachs (Pennsylvania State University).

\section{Notes}

1 Empowerment lite is "a version of empowerment pared of any confrontation with the embedded social and power relations that produce societal and material inequities" (Cornwall, 2018, p. 3).

2 Originally from Le Sauze, D. (2000). “A Community Approach...”, Yemaya, Issue 5, December 2000.

\section{References}

Ababouch, Lahsen, and Carolu, C. (2015). "Fisheries and aquaculture in the context of blue economy." Feeding Africa 2 (21-23 October):13.

Agbebi, F.O., and Fagbote, T.A. (2012). "The role of middlemen in fish marketing in Igbokoda fish market, Ondo-state, south western Nigeria." International Journal of Development and Sustainability 1 (3):880-888.

Agbontale, O. (2009, October 25-28). "Motivational factors responsible for women involvement in fish processing and marketing around Lake Kainji." In 24th annual conference of the fisheries society of Nigeria (FISON), 57-60, Akure, Nigeria.

Aladetohun, N. (2010, October 25-29). "Microfinance and aquaculture development for rural women in Nigeria." In 25th annual conference of the fisheries society of Nigeria (FISON), 661-667, Lagos, Nigeria.

Alder, J., and Sumaila, U.R. (2004). "Western Africa: a fish basket of Europe past and present." Journal of Environment and Development 13 (2):156-178. doi: 10.1177/1070496504266092.

Aregu, L., Choudhury, A., Rajaratnam, S., Locke, C., and McDougall, C. (2018). "Gender norms and agricultural innovations: insights from six villages in Bangladesh." Journal of Sustainable Development 11 (4):270-287. 
Aregu, L., Rajaratnam, S., McDougall, C., Johnstone, G., Wah, Z.Z., Nwe, K.M., Akester, M., Grantham, R., and Karim, M. (2017). "Gender in Myanmar's small-scale aquaculture sector." CGIAR Research Program on Fish Agri-Food Systems. Program Brief: FISH-2017-12. Penang, Malaysia.

Ashaletha, S., Ramachandran, C., Sheela, I., Diwan, A.D., and Sathiadhas, R. (2002). "Changing roles of fisherwomen of India - Issues and perspectives." Proceedings of International Conference on Women in Fisheries, 21-43, Mumbai, India.

Aswathy, P., and Kalpana, K. (2018). "Women's work, survival strategies and capitalist modernization in South Indian small-scale fisheries: the case of Kerala." Gender, Technology and Development 22(3):205-221. doi: 10.1080/09718524.2019.1576096.

Aswathy, P., and Kalpana, K. (2019). "Good woman, bad woman: social control and self-regulation in Kerala's artisanal fisheries." Women's Studies International Forum, 74(October 2018):196-203. doi: 10.1016/j.wsif.2019.04.006.

Ayinla, O.A. (2003, December 8-12). "Integrated fish farming: a veritable tool for poverty alleviation/ hunger eradication in the Niger delta region." In 18th annual conference of the fisheries society of Nigeria (FISON), 41-50, Owerri, Nigeria.

Ayoola, S. (2010). "Sustainable fish production in Africa." African Journal of Food Agriculture Nutrition and Development 10 (5):1-9.

Belton, B., and Thilsted, S.H. (2014). "Fisheries in transition: food and nutrition security implications for the global South.” Global Food Security 3 (1):59-66.

Béné, C., Arthur, R., Norbury, H., Allison, E.H., Beveridge, M., Bush, S., Campling, L., Leschen, W., Little, D., Squires, D., Thilsted, S.H., Troell, M., and Williams, M. (2016). "Contribution of fisheries and aquaculture to food security and poverty reduction: assessing the current evidence." World Development 79:177-196. doi: 10.1016/j.worlddev.2015.11.007.

Bennett, E. (2005). “Gender, fisheries and development.” Marine Policy 29 (5):451-459. doi: 10.1016/j. marpol.2004.07.003.

Biswas, N. (2011). "Turning the tide: women's lives in fisheries and the assault of capital." Economic and Political Weekly XLVI (51):53-60.

Biswas, N. (2017). "Towards gender-equitable small-scale fisheries governance and development: a handbook in support of the implementation of the voluntary guidelines for securing sustainable small-scale fisheries in the context of food security and poverty eradication." Rome, Italy: Food and Agriculture Organization of the United Nations.

Biswas, N. (2018). "Where have all the women gone?" Yemaya: ICSF's Newsletter on Gender and Fisheries 57:7.

Britwum, A.O. (2006). "The gendered dynamics of production relations in Ghanaian coastal fishing." Feminist Africa 12:69-85. Available at: www.feministafrica.org/uploads/File/Issue_12/fa12_feature_br itwum.pdf.

Browne, P.B. (2002). "Women do fish : a case study on gender and the fishing industry in Sierra Leone." Working Paper No. 36256, Penang, Malaysia: WorldFish.

Brugere, C., and Allison, E.H. (2008). "Livelihood diversification in coastal and inland fishing communities : misconceptions, evidence and implications for fisheries management." Available at: https://doi.org /10.13140/RG.2.2.15022.51523.

Brugere, C., and Williams, M. (2017). "Profile: women in aquaculture." Available at: https://genderaquafi sh.org/portfolio/women-in-aquaculture/.

Campling, L., Havice, E., and Mccall Howard, P. (2012). "The political economy and ecology of capture fisheries: market dynamics, resource access and relations of exploitation and resistance." Journal of Agrarian Change 12 (2-3):177-203. doi: 10.1111/j.1471-0366.2011.00356.x.

Choudhury, A., and McDougall, C. (2018). "Gendered ownership of aquaculture resources: insights from two villages in Bangladesh." CGIAR Research Program on Fish Agri-Food Systems, Penang. FISH-2018-19.

Choudhury, A., McDougall, C., Rajaratnam, S., and Park, C.M.Y. (2017). Women's empowerment in aquaculture: two case studies from Bangladesh. Rome, Italy: Food and Agriculture Organization of the United Nation/Penang, Malaysia:WorldFish.

Cole, S., McDougall, C., Kaminski, A., Kefi, A., Chilala, A., and Chisule, G. (2018). "Postharvest fish losses and unequal gender relations: drivers of the social-ecological trap in the Barotse Floodplain fishery, Zambia." Ecology and Society 23 (2), 1-13.

Cohen, P.J., Allison, E.H., Andrew, N.L., Cinner, J., Evan L.S., Fabinyi, M., Garces, L.R., Hall, S.J., Hicks, C.C., Hughes, T.P., Jentoft, S., Mills, D.J., Masu, R., Mbaru, E.K., Ratner, B.D. (2019). "Securing a 


\section{Surendran Rajaratnam et al.}

just space for small-scale fisheries in the blue economy." Frontiers in Marine Science 6 (April):1-8. doi: 10.3389/fmars.2019.00171.

Connelly, M.P., and MacDonald, M. (1983). "Women's work: domestic and wage labour in a Nova Scotia Community.” Studies in Political Economy 10 (1):45-72. doi: 10.1080/19187033.1983.11675671.

Cornwall, A. (2018). “Beyond 'empowerment lite': women's empowerment, neoliberal development and global justice.” Cadernos Pagu 52,1-30.

Davies, R.M., and Davies, O.A. (2009). "Traditional and improved fish processing technologies in Bayelsa state, Nigeria.” European Journal of Scientific Research 26(4): 539-548.

De, H.K., Chattopadhyay, D. N., Radheyshyam, Saha, G. S., Dash, A. K., Pal, S., \& Satpati, T. S. (2012). "Strengthening the livelihoods of rural women through polyculture of carps in seasonal ponds." Indian Journal of Fisheries 59 (3):137-141.

De, H.K., and Pandey, D.K. (2014). "Constraints to women's involvement in small scale aquaculture: an exploratory study.” International Journal of Agricultural Extension 2(1):81-88.

dela Pena, L., and Marte, C.L. (2001). "The plight of older women in a fishing village : the women fish traders of Bugtong Baton, Aklan, Central Philippines.” In M.J. Williams, M.C. Nandeesha,V.P. Corral, E. Tech, and P S. Choo (eds.), International symposium on women in Asian fisheries: fifth Asian fisheries forum, 13 November 1998, Chiang Mai, Thailand. Penang, Malaysia: ICLARM, 165-172.

FAO. (2020). The state of world fisheries and aquaculture 2020: sustainability in action. Rome. https://doi. org/10.4060/ca9229en

Fiorella, K.J., Camlin, C.S., Salmen, C.R., Omondi, R., Hickey, M.D., Omollo, D.O., ...\& Brashares, J.S. (2015). "Transactional fish-for-sex relationships amid declining fish access in Kenya." World Development 74:323-332. doi: 10.1016/j.worlddev.2015.05.015.

Frangoudes, Katia, and Gerrard, S. (2018). “(En)Gendering change in small-scale fisheries and fishing communities in a globalized world.” Maritime Studies 17:117-124.

Fröcklin, S., De La Torre-Castro, M., Lindström, L., \& Jiddawi, N.S. (2013). "Fish traders as key actors in fisheries: gender and adaptive management.' Ambio 42 (8):951-962. doi: 10.1007/s13280-013-0451-1.

Funge-Smith, S., and Bennett, A. (2019)." A fresh look at inland fisheries and their role in food security and livelihoods." Fish and Fisheries, 20(2), 1176-1195. 1-20. doi: 10.1111/faf.12403.

Golden, C.D., Seto, K.L., Dey, M.M., Chen, O.L., Gephart, J.A., Myers, S.S., .. \& Allison, E.H. (2017). "Does aquaculture support the needs of nutritionally vulnerable nations?" Frontiers in Marine Science 4 (May). doi: 10.3389/fmars.2017.00159.

Greenpeace International. (2019). "A waste of fish: food security under threat from the fishmeal and fish oil industry in West Africa.” Retrieved December 10, 2019 from https://www.greenpeace.org/internat ional/publication/22489/waste-of-fish-report-west-africa/.

Halim, S. (2004). "Marginalization or empowerment? Women's involvement in shrimp cultivation and shrimp processing plants in Bangladesh." Women, gender and discrimination, 95-112. Retrieved from https ://pdfs.semanticscholar.org/4bc8/d2a6e3e80e2647b4c2a6569e3fcbe499544d.pdf

Hapke, H.M., and Ayyankeril, D. (2004). "Gender, the work-life course, and livelihood strategies in a South Indian fish market.” Gender, Place and Culture 11 (2):229-256. doi: 10.1080/0966369042000218473.

Harper, S., Zeller, D., Hauzer, M., Pauly, D., \& Sumaila, U.R. (2013). "Women and fisheries: contribution to food security and local economies." Marine Policy 39 (1):56-63. doi: 10.1016/j.marpol.2012. 10.018 .

Hicks, C.C., Cohen, P.J., Graham, N.A.J., Nash, K.L., Allison, E.H., D’Lima, C., ... \& MacNeil, M.A. (2019). "Harnessing global fisheries to tackle micronutrient deficiencies." Nature 574 (7776):95-98. doi: 10.1038/s41586-019-1592-6.

Ibrahim, H.I., Kigbu,A.A., and Mohammed, R. (2011). “Women's experiences in small scale fish processing in Lake Feferuwa fishing community, Nasarawa State, Nigeria." Livestock Research for Rural Development 23 (3):1-8.

Islam, M.D.S. (2008). "From sea to shrimp processing factories in Bangladesh: gender and employment at the bottom of a global commodity chain." Journal of South Asian Development 3 (2):211-236. doi: 10.1177/097317410800300202.

Jeebhay, M.F., Robins, T.G., and Lopata, A.L. (2004). "World at work: fish processing workers." Occupational and Environmental Medicine, 61(5), 471-474.

Kamau, P., and Ngigi, S. (2013). "Potential for women fish traders to upgrade within the fish trade value chain: evidence from Kenya.” DBA Africa Management Review 3 (2):93-107.

Kleiber, D., Frangoudes, K., Snyder, H.T., Choudhury, A., Cole, S.M., Soejima, K., Pita, C., Santos, A., McDougall, C., Petrics, H., and Porter, M. (2017). "Promoting gender equity and equality through the 
small-scale fisheries guidelines: experiences from multiple case studies.” In Jentoft, S., Chuenpagdee, R., Barragán-Paladines, M.J., Franz,N. (Eds.). The small-scale fisheries guidelines. Cham: Springer, 737-759.

Kleiber, D., Harris, L.M., and Vincent, A.C.J. (2015). "Gender and small-scale fisheries: a case for counting women and beyond." Fish and Fisheries 16 (4):547-562. doi: 10.1111/faf.12075.

Kumar, P., and Dey, M.M. (2006). "Nutritional intake and dynamics of undernourishment of farm households in rural India." Indian Development Review 4 (2):269-284.

Kusakabe, K. (2002). "Gender issues in small scale inland fisheries in Asia: women as an important source of information." New approaches for the improvement of inland capture fishery statistics in the Mekong Basin. Food and Agriculture Organization of the United Nations, Mekong River Commission, Government of Thailand and Government of the Netherlands. September 2002. Accessed 28 May 2019.

Kusakabe, K., Sereyvath, P., Suntornratana, U., and Sriputinibondh, N. (2006). "Women in fish border trade: the case of fish trade between Cambodia and Thailand." In P.S. Choo, S.J. Hall, and M.J.Williams (eds.), Global symposium on gender and fisheries (Seventh Asian Fisheries Forum, 1-2 December 2004), Penang, Malaysia:WorldFish Center, 91-102.

Kusakabe, K., Sereyvath, P., Suntornratana, U., and Sriputinibondh, N. (2008). "Gendering border spaces: impact of open border policy between Cambodia-Thailand on small-scale women fish traders." African and Asian Studies 7(1):1-17. doi: 10.1163/156921008x273079.

Kwena, Z.A., Camlin, C.S., Shisanya, C.A., Mwanzo, I., \& Bukusi, E.A. (2013). "Short-term mobility and the risk of HIV infection among married couples in the fishing communities along Lake Victoria, Kenya." PLoS ONE 8 (1), 1-7. doi: 10.1371/journal.pone.0054523.

Lastarria-Cornhiel, S. (2006). "Feminization of agriculture: trends and driving forces." Background Paper for the World Development Report 2008. Rimisp-Latin American Center for Rural Development. Accessed 24 May 2019. Retrieved from http://siteresources.worldbank.org/INTWDRS/Resourc es/477365-1327599046334/8394679-1327599874257/LastarriaCornhiel_FeminizationOfAgri.pdf.

Lebel, L., Ganjanapan, S., Lebel, P., Somountha, M., Trinh, T.T.N., Bastakoti, G.B., Chitmanat, C. (2011). "Gender, commercialization and the fisheries-aquaculture divide in the Mekong region." In Water rights and social justice in the Mekong Region, 115-147. doi: 10.4324/9781849775472.

Lentisco, A., and Lee, R. (2015). A review of women's access to fish in small-scale fisheries. FAO Fisheries and Aquaculture Circular No. 1098, Rome, Italy: Food and Agriculture Organization of the United Nation.

Locke, C., Muljono, P., McDougall, C., and Morgan, M. (2017). "Innovation and gendered negotiations: insights from six small-scale fishing communities." Fish and Fisheries, 18(5) :1-15. doi: 10.1111/faf.12216.

Msangi, S., Kobayashi, M., Batka, M., Vannuccini, S., Dey, M.M. and Anderson, J.L., (2013). "Fish to 2030: prospects for fisheries and aquaculture." World Bank Report 83177 (1):102.

Nandeesha, M.C. (1994). “Aquaculture in Cambodia.” Infofish International (2):42-48.

Overa, R. (2007). "When men do women's work: structural adjustment, unemployment and changing gender relations in the informal economy of Accra, Ghana." Journal of Modern African Studies 45 (4):539563. doi: 10.1017/S0022278X0700287X.

Pini, Barbara, and Leach, B. (2011). "Transformations of class and gender in the globalized countryside." 1-23. In Leach, Belinda (Ed.). Reshaping Gender and Class in Rural Spaces. London: Routledge.

Rajaratnam, S. Cole, S.M., Longley, C., Kruijssen, F., \& Sarapura, S. (2016). "Gender inequalities in access to and benefits derived from the natural fishery in the Barotse floodplain, Zambia, Southern Africa." Asian Fisheries Science 29 (Special Issue):49-71.

Rashid, M.U., Rahman, F, and Sultana, N. (2016). “Fish feed in Bangladesh: where are the women?” In Pyburn, Rhiannon, and Anouka van Eerdewijk (eds), A different kettle of fish? Gender integration in livestock and fish research.Volendam: LM Publishers.

Resurreccion, B.P. (2006). "Rules, roles and rights: gender, participation and community fisheries management in Cambodia's tonle sap region." Water Resources Development 22 (3):433-447. doi: 10.1080/07900620500482949.

Rubinoff, J.A. (1999). “Fishing for status: impact of development on Goa's fisherwomen.” Women's Studies International Forum 22 (6):631-644. doi: 10.1016/S0277-5395(99)00073-4.

Sari, I., McDougall, C., and Rajaratnam, S. (2017). "Women's empowerment in aquaculture: two case studies from Indonesia. " Food and Agriculture Organization of the United Nations, Rome, Italy/WorldFish, Penang, Malaysia.

Scarborough, W.J., Risman, B.J., and Meola, C. (2017). "Women's-group fishponds in Bangladesh: using gender structure theory to examine changes in the gender asset gap." Socius 3:1-19.

Shah, D. (2010). Women in fisheries. Case Studies: India. International Collective in Support of Fishworkers. Accessed on 30 May 2019. Retrieved from http://aquaticcommons.org/17143/. 


\section{Surendran Rajaratnam et al.}

Siamomua-Momoemausu, M.J. (2005). Gender collaboration: a case study of local resource management in Safa'i village, Samoa, Pacific voices: equity and sustainability in Pacific Islands fisheries. I. Novaczek, J. Mitchell, and J. Veitayaki (ed.), University of the South Pacific. Suva, Fiji: Institute of Pacific Studies, 209-220.

Smith, L.C., Ramakrishnan, U., Ndiaye, A., Haddad, L., Martorell, R. (2003). “The importance of women's status for child nutrition in developing countries.” Research Report 131.Washington, DC.: International Food Policy Research Institute.

Thilsted, S.H., Thorne-Lyman, A., Webb, P., Bogard, J.R., Subasinghe, R., Phillips, M.J., \& Allison, E.H. (2016). "Sustaining healthy diets: the role of capture fisheries and aquaculture for improving nutrition in the post-2015 era." Food Policy 61:126-131. doi: 10.1016/j.foodpol.2016.02.005.

Tlusty, M.F. Tyedmers, P., Bailey, M., Ziegler, F., Henriksson, P. J. G., Béné, C., ...\& Jonell, M. (2019). "Reframing the sustainable seafood narrative." Global Environmental Change 59 (September):101991. doi: 10.1016/j.gloenvcha.2019.101991.

Wahed, T., and Bhuiya, A. (2007). "Battered bodies and shattered minds: violence against women in Bangladesh." Indian Journal of Medical Research 126 (4):341-354.

Weeratunge, N., Snyder, K.A., and Sze, C.P. (2010). "Gleaner, fisher, trader, processor: understanding gendered employment in fisheries and aquaculture." Fish and Fisheries 11 (4):405-420. doi: 10.1111/j.1467-2979.2010.00368.x.

Williams, M. (2010). "Gender dimensions in fisheries.” In R.Q. Grafton, R. Hilborn, D. Squires, M. Trait, and M.J. Williams (eds), Handbook of marine fisheries conservation and management. New York: Oxford University Press, 72-86.

Williams, M. (2015). "Women in today's fisheries economy." Yemaya: ICSF's Newsletter on Gender and Fisheries 50:2-4. Retrieved from http://aquaticcommons.org/19635/1/Yemaya\%2050.pdf

World Bank. (2019). “Oceans, fisheries, and coastal economies.” Blue Economy. The World Bank Group. Accessed 15 August 2019. Retrieved from https://www.worldbank.org/en/topic/oceans-fisheries-and -coastal-economies\#1.

World Bank, FAO, WorldFish and ARD. (2012). Hidden harvest: the global contribution of capture fisheries. Report No. 66469-GLB. The World Bank, Washington, DC.

WorldFish Center. (2010). "Gender and fisheries: do women support, complement, or subsidize men's small-scale fishing activities?” Issues Brief No. 2108, 1-8.

Wrigley-Asante, C. (2011). "Women becoming bosses: changing gender roles and decision making in Dangme West District of Ghana." Ghana Journal of Geography 3:60-87.

Yea, S. (2012). "Troubled waters: trafficking of Filipino men into the long haul fishing industry through Singapore.” Singapore: Transient Workers Count, 2. Retrieved from https://twc2.org.sg/2013/01/06/ troubled-waters-trafficking-of-filipino-men-into-the-long-haul-fishing-industry-through-singapore/. 